\title{
THE CONTRIBUTION OF WEEDS IN REDUCING DIAPHORINA CITRI (ASIAN CITRUS PSYLLID) POPULATIONS ON MANDARIN TREES, IN TUXPAN, VERACRUZ, MEXICO
}

\author{
Almaguer-VARgas, G. ${ }^{1 *}$ - Botello-Castillo, M. D. ${ }^{1}-$ JACOBO-Blas, L. $^{1}$ - MAURICIO- \\ PÉREZ, J. M. ${ }^{1}$ - GONZÁleZ-HERNÁNDEZ, V. A. ${ }^{2}$ - CRUZ-HuERTA, N. ${ }^{2}$ - RAMÍrEZ, R. I. ${ }^{2}$ - \\ MONDRAGÓN-PEDRERO, G. ${ }^{1}-$ DE LA CRUZ, D. E. ${ }^{3}$ \\ ${ }^{I}$ Departamento de Fitotecnia, URUSSE, Universidad Autónoma Chapingo \\ Km. 38.5 Carretera 5 México-Texcoco, Chapingo, C. P. 56230, Estado de México, Mexico \\ ${ }^{2}$ Colegio de Posgraduados \\ Montecillo, Texcoco, Estado de México, Mexico \\ ${ }^{3}$ Universidad Tecnológica de la Huasteca Hidalguense \\ Carretera Huejutla-Chalahuiyapa s/n. Huejutla, Hidalgo, Mexico \\ *Corresponding author \\ e-mail:almaguervargas@hotmail.com,gustavoalmaguervargas@gmail.com; phone: +52-1-59- \\ $5108-9113$ \\ (Received $6^{\text {th }}$ Jan 2018; accepted $10^{\text {th }}$ Oct 2018)
}

\begin{abstract}
Mexican citrus production is presently at risk of decreasing significantly due to the presence of Huanglongbing (Candiadtus Liberribacter spp), whose vector is Diaphorina citri ((Kuwayama) (Hemiptera: Psyllidae) (Asian citrus psyllid). The aim of this study was to evaluate the influence of weeds on the number of adults and nymphs, photosynthesis, nutritional status, presence of insects, and the total number of weeds. The experiment was carried out in the region of Tuxpan, located in Veracruz, Mexico. Two-year-old mandarin, cultivar 'Ortanique' (Citrus reticulata x C. sinensis) (L) was used. Four treatments were established in three periods: citrus trees covered with mesh and grown among weeds; citrus trees covered with mesh and grown without weeds; citrus trees without any type of protection, but with adequate weed control, and citrus trees in the presence of weeds. For the mesh treatments, coverings were made of high-density polyethylene anti-aphid mesh $(55 \times 30$ threads per inch). Twenty trees were randomly selected for each treatment. According to the Tukey statistical test, the mesh and weed treatments were the ones that obtained the lowest number of Diaphorina citri ((Kuwayama) (Hemiptera: Psyllidae) adults and nymphs per tree and had good nutritional status, photosynthesis and number of weeds during the sampling periods. In conclusion, the presence weeds helped to reduce Diaphorina citri populations.
\end{abstract}

Keywords: Huanglongbing, Citrus, population dynamics, management sustainable, diaphorina control

\section{Introduction}

Huanglongbing (HLB, Candidatus Liberibacter spp) is the most devastating citrus disease responsible for the death of millions of trees worldwide (Halbert and Manjunath, 2004; Bove, 2006). In Mexico, this disease was predicted to destroy more than half of their orange and grapefruit production in only five years (Salcedo et al., 2010). HLB is caused by a nopropagating persistent gram-negative bacteria transmitted by psyllids inside whom they reproduce, but are not transmitted to other generations (Chiou-Nan, 1998). The importance of this bacteria lies in the fact that it can shorten the tree's lifecycle affecting and reducing their production (Chen et al., 2009).

HLB was detected in citrus for the first time in Colima, Mexico on April 7, 2010 (Robles et al., 2013). The volume of production of the state has been reduced from 2011 to 2015 by $61 \%$, and yield $\left(\mathrm{t}^{\circ} \mathrm{ha}^{-1}\right)$ by $55.6 \%$ (SAGARPA-SIAP, 2016). Citrus cultivation areas and 
production in Florida have been reduced in the last 20 years, by $40 \%$ and $49 \%$, respectively, where HLB remains as one of the main causes (Álvarez et al., 2016). In an unprotected lime grove located in Colima, Mexico, Robles et al. (2013) observed that in only one year more than $50 \%$ of the trees were infected with HLB.

HLB is a disease that has no cure as yet (Bové, 2006), for this, the best way to coexist with it, is to control the vector, the Asian citrus psyllid (ACP), Diaphorina citri (Kuwayama) (Hemiptera: Psyllidae), by spraying insecticides in their foci of infection (Robles et al., 2013), removing infected trees, and propagating healthy plants (Belasque et al., 2010).

In Sao Paulo, Brazil, Diaphorina citri, and HLB have been controlled through the identification and eradication of symptomatic trees, and by applying insecticides to large extensions of farms land (Belasque et al., 2010). However, these same authors affirmed that due to the excessive use of insecticides, long-term solutions will have to be looked into. In Brazil and the United States, for example, up to twelve applications are made per year, which can lead to contamination and insect resistance (Grafton-Cardwell et al., 2013; Martinez, 2011).

Monzo et al. (2014) found that the monthly insecticide applications can negatively affect the populations of ACP natural enemies. Tiwari et al. (2011) observed that Diaphorina citri populations collected in 2009 and 2010 showed lower susceptibility to insecticides such as imidacloprid in relation to a population that was in observation in laboratory conditions since 2000, which implies the development of resistance of the psyllids.

Now faced with this serious phytosanitary problem, the biological control of this pest must be established through the use of predators, parasitoids, and entomopathogens, especially Tamarixia radiata (Qureshi et al., 2009).

Another feasible alternative is weed management because it helps to increase predators population and parasitoids of phytophagous by improving the availability of alternative food, breeding sites, and creates an habitat for the beneficial insects (Ali and Agrawal, 2014; Altieri and Whitcomb, 1979; Andorno and López, 2014; Banks and Gagic, 2016; Barberi et al., 2010; Blanco and Leyva, 2007; Boivin et al., 2012; Colloff et al., 2013; Dahlin and Ninkovic, 2013; Gurr et al., 2003; Kumar, 2017; Macfadyen et al., 2015; Nave et al., 2016; Thomson and Hoffmann, 2010; Parolin et al., 2012; Veres et al., 2013; Vialatte et al., 2017).

In the particular case of citrus, Collofff et al. (2013) observed that citrus fields with little thrip damage were densely and diversely covered with high predator populations, while fields with high percentages of damage were cleared of weeds. Ortega et al. (2011) found that the incidence of $D$. citri was decreased in low-density plots and in the abundance of weeds. In Florida, spiders, ants, and Coccinellids have caused natural mortality of Diaphorina citri nymphs, by $90 \%$. However, the relation between weeds and Diaphorina in controlled environments has not yet been determined.

The aim of this research was to analyze the influence of weeds on the number of Diaphorina citri adults and nymphs, gaseous exchange, nutritional status of leaves, number of insects, and weed type presented in controlled environments at orchard of Mandarin cultivar 'Ortanique' (Citrus reticulata X C. sinensis L.).

\section{Materials and methods}

\section{Location}

The study was carried out in a mandarin orchard, located in Tuxpan, Veracruz, Mexico, in the northern region of the state, known as the Huasteca Baja, at coordinates $20^{\circ} 57^{\prime} 7.639^{\prime \prime}$ NL and $-97^{\circ} 24^{\prime} 15.660^{\prime}$ ' WL. Boundaries to the north with Tamiahua 
and Naranjos, to the south with Tihuatlán and Cazones de Herrera, to the east with the Gulf of Mexico and to the west with Álamo, Temapache, Veracruz, México. The climate is classified as tropical, with an annual average temperature of $24{ }^{\circ} \mathrm{C}$, and an average annual rainfall of 1,241 mm (Comisión Nacional del Agua, 2014). Based on soil analysis, Vertisol is the principal soil type, not saline, poor in $\mathrm{N}, \mathrm{P}$, and micronutrients; its $\mathrm{pH}$ is 7.24 , contains $3.7 \%$ organic matter content, and has high $\mathrm{Ca}$, $\mathrm{Mg}$, and $\mathrm{K}$ contents.

\section{Plant material and experimental setup}

The variety used in this study was the Mandarin cultivar 'Ortanique' (Citrus reticulata X C. sinensis L.), grafted on the rootstock 'Citrus Volkameriano' was used in this experiment. The plants were established on February 2012, using a rectangular planting arrangement, $6 \mathrm{~m} \times 3.5 \mathrm{~m}$. Before the experiment was established (February 2014), land preparation was carried out by passing a disc plow once and the disc harrow twice. At the moment of establishment the disc harrow was passed between rows and for adequate weed control glyphosate was applied. Foliar fertilization was applied three times per year with Boron, Calcium, Zinc, Manganese, Iron, and Copper. Zeolite and ammonium sulfate was also applied via drip irrigation in close proximity to the trees. The manufacturer of the applied experimental equipment was "Solo" of twenty liters. Stem shoots (suckers) were removed every three to four months.

\section{Treatments}

The four evaluated treatments are described in Table 1.

Table 1. Treatments applied to 'Ortanique' Mandarin trees, in Tuxpan, Veracruz, Mexico, to observe the incidence of Diaphorina citri (Asian citrus psyllid) adults and nymphs

\begin{tabular}{c|c}
\hline Treatment & Description \\
\hline Treatment 1 & Trees covered with mesh and grown with weeds $(\mathrm{M}+\mathrm{W}) ;$ \\
Treatment 2 & Trees covered with mesh and in the absence of weeds $(\mathrm{M}-\mathrm{W}) ;$ \\
Treatment 3 & Trees grown without any type of protection and with weeds $(\mathrm{P}+\mathrm{A}) ;$ \\
Treatment 4 & Trees grown without any type of protection and without weeds (P-A); \\
\hline
\end{tabular}

In order to cover the trees with mesh (T1 and T2), two high-density polyethylene mesh houses $(139.7 \times 76.2$ per $\mathrm{cm})$, of crystal color $36 \mathrm{~m} \times 36 \mathrm{~m}$ were constructed $3 \mathrm{~m}$ high. Each structure was of $1296 \mathrm{~m}^{2}$ covering 54 trees. The purpose of these two mesh covering was to maintain the $D$. citri insects in one place preventing them from entering or leaving the area, and by this means to study in a controlled manner the behavior of the number of adults and nymphs, with and without weeds.

The weed treatments were left to grow freely between rows, up to a distance of $1.5 \mathrm{~m}$ from the stem. In the no-weed treatments, these were completely eliminated in the corresponding plots, by applying glyphosate $\left(7.5 \mathrm{~mL} \mathrm{~L}^{-1}\right)$ dissolved in water.

Three sampling periods were performed. In each period the mesh houses were established in a different place, but within the same orchard, ensuring that there was homogeneity among selected trees for all treatments and dates.

The mesh treatments was established on May 23rd for the first evaluation period and sampling was carried out on May 30th, June 6th, June 20th, July 4th, and July 11th; the 
second evaluation period was from August 8th to October 11th, 2014 and sampling dates were from August 16th and 23rd, September 6th and 20th, and October 4th and 11th. For the third evaluation period, the mesh was installed on February 25th and sampling was on March the 3rd, 10th and 17th, and April 15th.

\section{Measured variables}

\section{Number of Diaphorina citri adults and nymphs}

In order to count the number of adults and nymphs of the psyllids, a wooden frame $\left(1 \mathrm{~m}^{2}\right)$ was placed at the four cardinal points of 20 mandarin trees, per each treatment, (north, south, east, and west), at a height of $75 \mathrm{~cm}$ above soil level; after, the number of Diaphorina citri adults and nymphs were count, with accountant portable equip. With this data the average number of Diaphorina citri adults and nymphs were calculated. The total of replicas of every treatment were 80 .

The selected citrus trees showed the following characteristics: homogeneous, healthy, same height and appearance, and of similar bud sprouting and shoot characteristics; in all treatments, trees that were found growing on edge of the plots were not sampled.

In each evaluation period, the mesh was rotated to a different position in the orchard. The trees were tip pruned and data collection was started again. The population kinetics of adults and nymphs of Diaphorina citri were also evaluated by plotting the amount of Diaphorinas registered on the different dates in each of the evaluation periods per tree.

\section{Total number of weeds and insects in the soil}

In order to know the total number of weeds and insects found in the soil for the different treatments of each period, a wooden one square meter frame was thrown fifty times, and in the part where it felled the weeds and insects present were counted. In order to know their type, weeds, and existing insects were collected and identified in the Chapingo Autonomous University.

\section{Nutrient foliar diagnosis}

Sampling and soil analysis was carried out in the study plot, along with a foliar diagnosis of the trees of the experiment. Eighty leaves from 20 trees of each treatment were sampled randomly. The nutritional status of the weeds was also evaluated by sampling 80 leaves taken randomly from the most frequent plants.

The nutrients were evaluated by the following methods (Etchevers, 2001): N, by the method proposed by Kjeldahl. $\mathrm{P}$ by the Bray method. $\mathrm{K}$ by flame emission spectrophotometry. Ca and $\mathrm{Mg}$ by Volumetry (EDTA $0.01 \mathrm{~N}$ ). $\mathrm{Fe}, \mathrm{Cu}, \mathrm{Zn}$, and $\mathrm{Mn}$ were extracted and read in an atomic absorption spectrophotometer. B was determined by the azomethine- $\mathrm{H}$ method. In the case of soil analysis, organic matter (OM) was quantified by the Walkley and Black method. The $\mathrm{pH}$ was measured in a 1:2 soil-water ratio by a potentiometer. Electrical conductivity was read in the $\mathrm{pH}$ extract using the Hanna apparatus Model 991201. Cation exchange capacity, (exchangeable cations) was extracted with ammonium acetate $1.0 \mathrm{~N} \mathrm{pH} 7.0$. 


\section{Gas exchange of plants}

The following variables were evaluated: net photosynthesis rate $\left(\mathrm{A}, \mu \mathrm{mol} \mathrm{m} \mathrm{m}^{-2} \mathrm{~s}^{-1}\right)$,

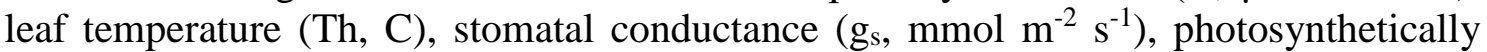

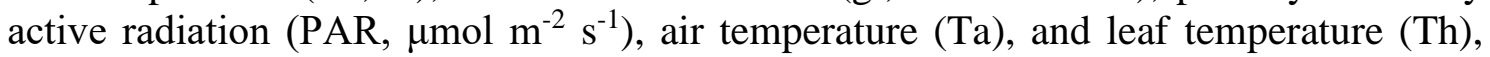
recorded on a young and mature leafs at each of three canopy layers (upper, middle, and lower), of three trees per each treatment. A portable photosynthesis system PPSystem TPS2 $^{\text {TM }}$ (Amesbury, MA, USA) was used in open mode.

\section{Experimental design}

A completely randomized block design with different number of replicates was used, depending on the variable. In the case of total number of diaphorinas, 20 trees were selected and for each tree psyllids were counted in a square meter at each cardinal point, generating 80 repetitions.

\section{Statistical analysis}

Analyses of variance and Tukey tests for multiple comparisons of means $(\alpha=0.05)$ in all measured variables were performed using the GLM procedure of the Statistical Analysis System (SAS, 2014) program.

\section{Results and discussion}

\section{Average number of Diaphorina citri adults and nymphs per square meter of mandarin trees, in three sampling periods}

The weed treatments established with mesh were the ones that showed lesser amounts of Diaphorina ( $\mathrm{P}<0.05)$, averaging 1.5 adults per square meter of the canopy (Table 2). In contrast, the trees covered with mesh and those free of weeds presented up to 72.49 adults per square meter of the canopy. A similar trend was observed with nymphs. This implies that the presence of weeds reduces the number of Diaphorinas.

Barberi et al. (2010) and Gurr et al. (2003) indicated that the multifunctioning of agricultural biodiversity allows pest suppression, especially because more diversity increases the number of predators and parasitoids in a third trophic level, which coincides with Banks and Gagic (2016), Vialatte et al. (2016).

\section{Population kinetics of Diaphorina citri adults}

All treated trees showed a tendency to start with low numbers of Diaphorina adults in the three evaluated periods, but at 15-30 days, their number increased significantly in mesh and no-weed treatments (Fig. 1).

The opposite happened to the mesh and weed treatments $(\mathrm{M}+\mathrm{A})$; the number of Diaphorina adults that was present in the trees established with weeds, were low in the three evaluation periods, tending to zero. Only a small increase was observed at the beginning of the first sampling period and practically remained at zero.

The spring-summer cycle (May to July) was registered as the most favorable period for psyllid reproduction, reaching almost 300 adults per $\mathrm{m}^{2}$ per canopy. This is attributed to the temperature, humidity, and the presence of shoots which were the most suitable conditions for their development. The presence of weeds significantly reduced 
(Table 2) the incidence of the insect that transmits HLB in Mandarin trees, even without covering the fields with anti-aphid meshes.

Table 2. Average number of Diaphorina citri adults and nymphs per square meter recorded at three sampling periods for weed and no-weed treatments, obtained on the mandarin cultivar 'Ortanique', in Tuxpan, Veracruz, Mexico

\begin{tabular}{c|c|c|c|c|c|c}
\hline $\begin{array}{c}\text { Evaluation } \\
\text { period }\end{array}$ & \multicolumn{2}{|c|}{$\begin{array}{c}\text { First period (May- } \\
\text { June 2014) }\end{array}$} & \multicolumn{2}{c|}{$\begin{array}{c}\text { Second period (August- } \\
\text { October 2014) }\end{array}$} & \multicolumn{2}{c}{$\begin{array}{c}\text { Third period (February- } \\
\text { April 2015) }\end{array}$} \\
\hline Treatments & Adults & Nymphs & Adults & Nymphs & Adults & Nymphs \\
\hline M+A & $3.00 \mathrm{c}$ & $4.43 \mathrm{~b}$ & $0.43 \mathrm{c}$ & $0.19 \mathrm{~d}$ & $0.56 \mathrm{~b}$ & $0.55 \mathrm{c}$ \\
M-A & $72.49 \mathrm{a}$ & $10.48 \mathrm{a}$ & $12.1 \mathrm{a}$ & $14.74 \mathrm{a}$ & $25.40 \mathrm{a}$ & $14.16 \mathrm{a}$ \\
I+A & $1.73 \mathrm{c}$ & $10.67 \mathrm{a}$ & $0.77 \mathrm{c}$ & $1.85 \mathrm{c}$ & $1.29 \mathrm{~b}$ & $2.75 \mathrm{~b}$ \\
I-A & $11.30 \mathrm{~b}$ & $12.07 \mathrm{a}$ & $3.08 \mathrm{~b}$ & $7.71 \mathrm{~b}$ & $0.49 \mathrm{~b}$ & $2.37 \mathrm{~b}$ \\
HSD & 7.32 & 2.88 & 1.12 & 1.54 & 4.17 & 1.59 \\
\hline
\end{tabular}

Means with distinct letters in each column differ statistically (Tukey, $\mathrm{P} \leq 0.05$ ). $\mathrm{M}+\mathrm{A}=$ Mesh and weed treatments, $\mathrm{M}-\mathrm{A}=$ Mesh and no-weed treatments, $\mathrm{I}+\mathrm{A}=$ Open field and weed treatments, I-A = Open field and no-weed treatments

Ortega et al. (2011) in studying the seasonal abundance of Diaphorina citri (Hemiptera lividae), in Citrus fields located at Cazones, Veracruz, Mexico, indicated that the psyllid showed population peaks during the months of February, March, April, and July under favorable temperatures of 24 to $29^{\circ} \mathrm{C}$. Liu and Tsai (2000) mentioned that the optimal temperature range for APC development is between 25 and $28{ }^{\circ} \mathrm{C}$, showing high reproductive potential. In the present study, temperatures were higher than $34{ }^{\circ} \mathrm{C}$ in the middle and later part of July and throughout the month of August. During the other months, the maximum temperature fluctuated from 30 to $32{ }^{\circ} \mathrm{C}$, according to data obtained at the Tuxpan, Veracruz weather station. Adequate temperatures were presented in the three periods.

In a related study (De la Cruz, 2014), it was found that the decrease in both nymph and adult population occurred in the months that presented a considerably increased in rainfall, where September was the month that presented the highest reached volume, accumulating up to $377 \mathrm{~mm}$, this exceeding the amount mentioned by Hall et al. (2008).

Relative humidity is a factor that can directly affect nymphs and adults, because it was observed that on the dates where high relative humidity was presented, the number of psyllids decreased, this coinciding with Aubert (1987), who mentioned that D. citri populations do not survive humidity levels close to point of saturation, because it promotes fungal epizootics such as Hirsutella citriformis Speare and $H$. besseyi.

In the present study, relative humidity during the sampling periods fluctuated between $70-95 \%$. However, it is considered that the prolonged presence of weeds gradually reduces the presence of Diaphorina citri adults and nymphs.

De la Cruz (2014) find only 0.001-0.04 adults per sprout all around the year at orange orchards in Veracruz, México, with humid tropical climate; but when the orange citrus trees has a lot of young sprout, the populations rice to 0.4 , adults per sprout. The orange orchards management was traditional, with low control of insects and presence of weeds. In this document it was very low numbers of adults and nymphs (Table 2; Figs. 1 and 2), specially with open field and weed treatments. But we had high number when was applied the mesh and no-weed treatments. 
It is important to mention that HLB arrived in Colima, on April 2010, and has currently infected $100 \%$ of Mexican lime trees (Robles et al., 2013). In Yucatan, it was detected on August 2009, obtaining at 2014 an estimated infection percentage of 10\% without significantly reducing yields (May et al., 2015; SAGARPA-SIAP, 2016). This difference could be attributed to the fact that Colima has a warm dry climate and in the orchards more than four insecticide applications and weed control is required throughout the fields, while in Yucatan, almost no weed control is carried out, applying insecticides on average once per year, and because of its humid tropical climate, large amounts of weeds are manifested (May et al., 2015).

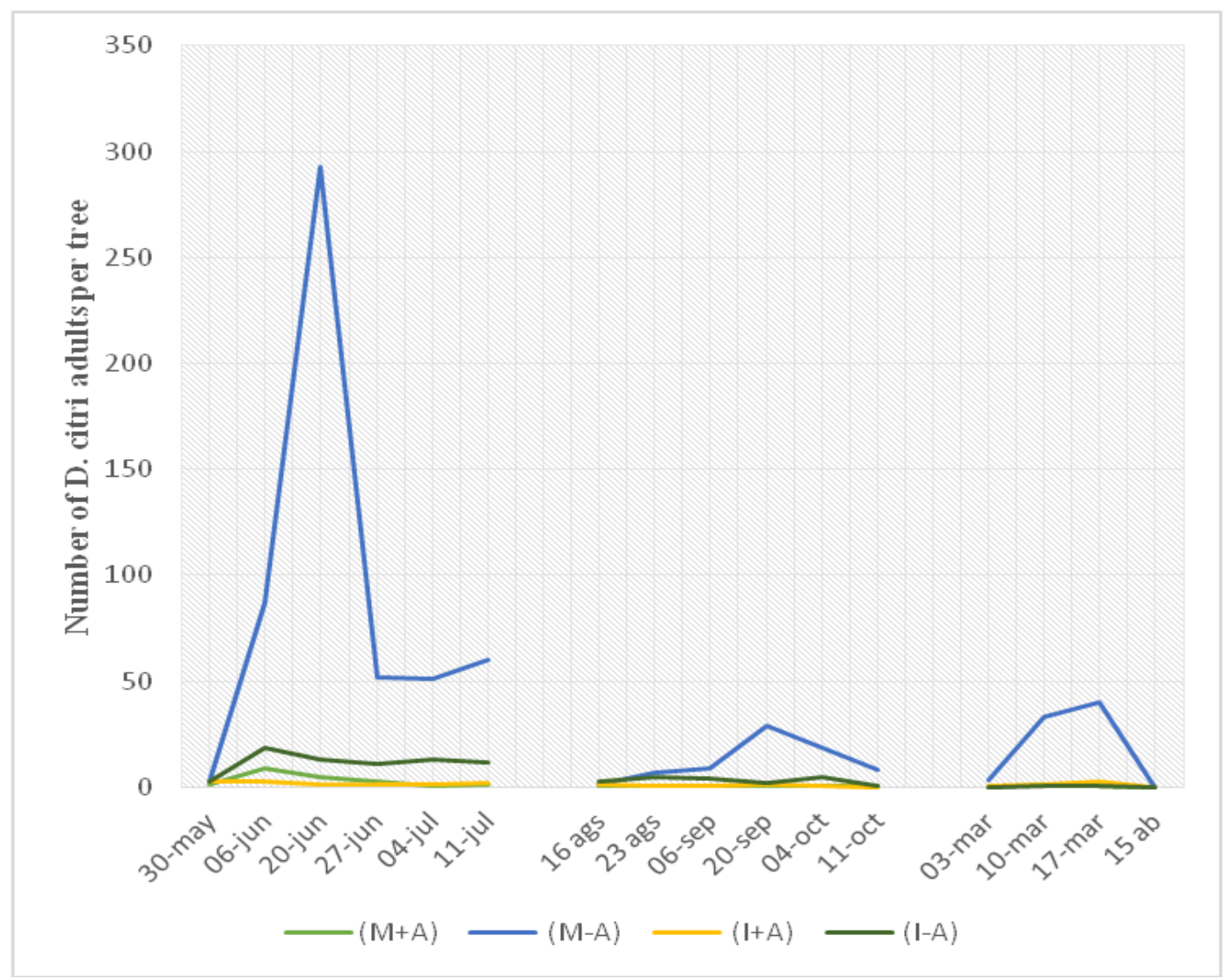

Figure 1. Population kinetics of D. citri adults during three evaluation periods (the first two in 2014 and the third in 2015) in 'Ortanique' mandarin fields located in Tuxpan, Veracruz, Mexico. $M+A=$ Mesh and weed treatments, $M-A=$ Mesh and no-weed treatments, $I+A=$ Open field and weed treatments, $I-A=O p e n$ field and no-weed treatments

Gurr et al. (2003) affirmed that an increase in biodiversity often reduces pests by increasing the predators and parasitoids populations. Monzo et al. (2014) indicated that monthly insecticide application in controlling psyllid can affect their natural enemy populations resulting in reduced predation on Dhiaphorina immature stages.

\section{Population kinetics of nymphs}

A similar trend was also observed as in adults (Figs. 1 and 2); there were greater amounts of nymphs in spring-summer (in all treatments), which confirms the above mentioned about the reproduction cycles of the insect. 


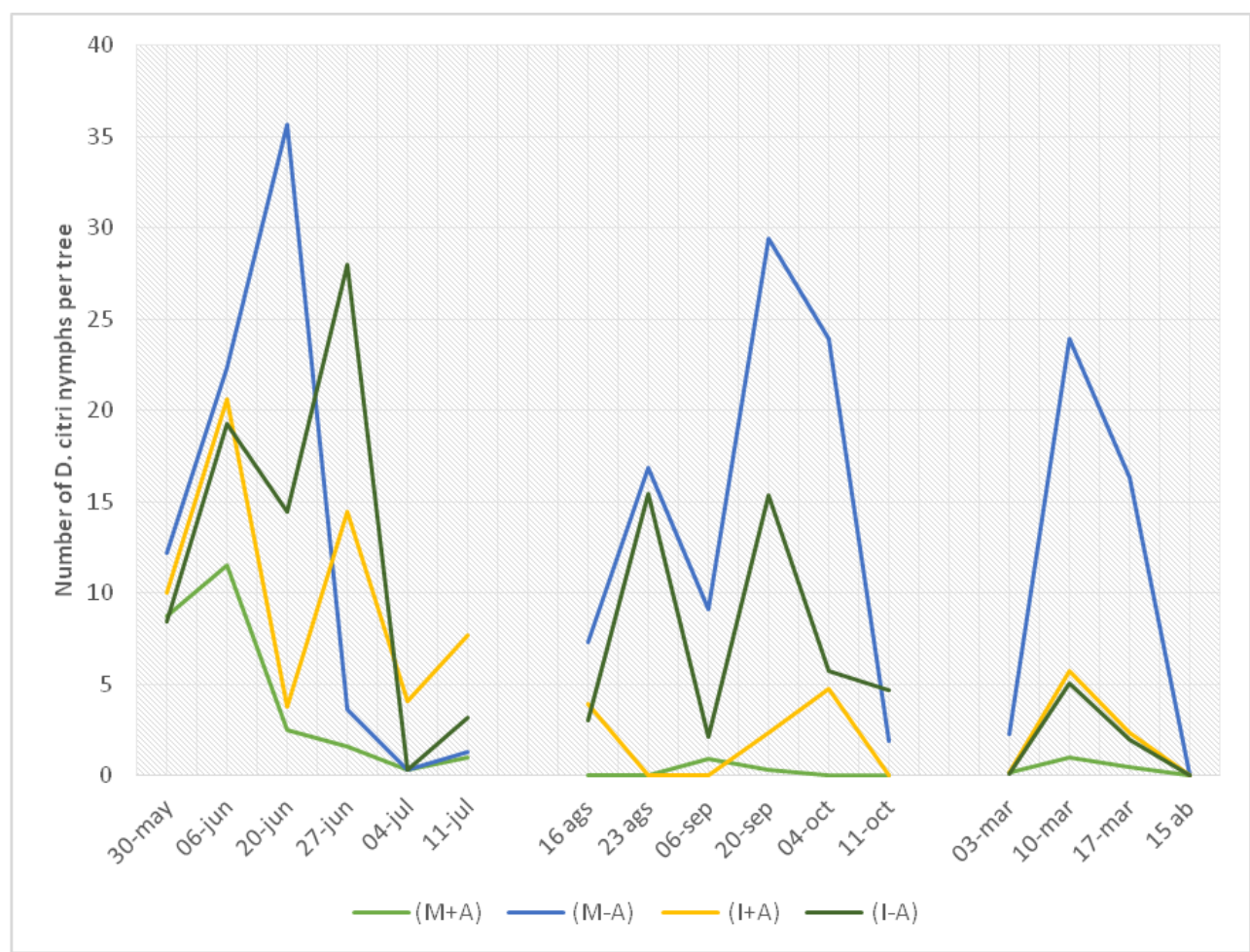

Figure 2. Population kinetics of D. citri nymphs during three evaluation periods (the first two in 2014 and the third in 2015) on 'Ortanique' mandarin fields, located in Tuxpan, Veracruz. $M+$ $A=$ Mesh and weed treatments, $M-A=$ Mesh and no-weed treatments, $I+A=$ Open field and weed treatments, $I-A=O p e n$ field and no-weed treatments

In addition, under favorable periods for insect proliferation (May to Sept), relative differences were noted between the minor treatments than in adults, suggesting that even in the presence of weeds the nymphs are able to reach adulthood, reason why weeds play an important part in this stage of their metamorphosis. But when reaching the adult stage, their population decreases.

No-weed treatments obtained the highest number of nymphs, then gradually increasing from May 30 to June 27; then decreasing for the first evaluation period. A similar trend was also shown for the other two evaluation periods. The mesh and weed treatments showed the tendency to have fewer Diaphorina nymphs in the second and third sampling period.

Several studies have demonstrated pests reduction due to the presence of weeds, whether they are plant germplasm (Andorno and Lopez, 2014; Tomaseto et al., 2016; Kumar, 2017; Ali and Agrawal, 2014) native vegetation within the orchard (Macfadyen et al., 2015; Thomson and Hoffmann, 2010), or adjacent vegetation (Atakan, 2010; Thomson and Hoffmann, 2009; Fig. 2), also, secondary plants have been used for the same purposes, improving efficiency and sustainability of the biological control that generates the natural enemies (Parolin et al., 2012).

\section{Total number of insects per square meter}

On comparing treatments, it is observed that weed treatments showed a high number of insects per square meter $(\mathrm{M}+\mathrm{A}$ and $\mathrm{I}+\mathrm{A})$, and when comparing the other 2 (no-weeds treatments) significant differences were observed (Table 3). 
Table 3. Total number of insects per square meter found on 'Ortanique' mandarin orchards, located in Tuxpan, Veracruz, Mexico, weed and no-weed treatments

\begin{tabular}{c|c|c|c}
\hline Treatment & $\begin{array}{c}\text { Average during first } \\
\text { evaluation period }\end{array}$ & $\begin{array}{c}\text { Average during second } \\
\text { evaluation period }\end{array}$ & $\begin{array}{c}\text { Average during third } \\
\text { evaluation period }\end{array}$ \\
\hline M+A & $22.94 \mathrm{a}$ & $18.36 \mathrm{a}$ & $19.02 \mathrm{a}$ \\
$\mathrm{I}+\mathrm{A}$ & $14.38 \mathrm{~b}$ & 14.76 & $13.45 \mathrm{~b}$ \\
$\mathrm{M}-\mathrm{A}$ & $0.15 \mathrm{c}$ & $0.24 \mathrm{c}$ & $0.20 \mathrm{c}$ \\
$\mathrm{I}-\mathrm{A}$ & $0.16 \mathrm{c}$ & $0.13 \mathrm{c}$ & $0.18 \mathrm{c}$ \\
\hline
\end{tabular}

$\mathrm{M}+\mathrm{A}=$ Mesh and weed treatments, $\mathrm{M}-\mathrm{A}=$ Mesh and no-weed treatments, $\mathrm{I}+\mathrm{A}=$ Open field and weed treatments, I-A = Open field and no-weed treatments. Means with different letters in each column differ statistically

This behavior is influenced by the incidence of depredators of this psyllid such as Coccinellids, Chrysopids, and Arachnids, found hiding in the weeds (Lomelí et al., 2010). In the present investigation, the mesh and weed treatments, were the one that had the least amount of Diaphorina citri adults and nymphs, obtaining averages of 227.56 weeds and 22 insects per square meter of soil, where arachnids, Coccinellids, Chrysopids, stinkbugs, and Ceraeochrysa sp, were most predominant species, among others

Since 1979, Altieri et al. have insisted that weeds can increase the biological control of insects. They claim that a dense weed extensions and high diversity usually have more beneficial insects, so weed manipulation could be a practice to increase biological control of insects like this experiment (Table 3); in fact, they have proposed that habitat diversification and organic soil management as the two pillars in converting the conventional system to a diversified low-input system (Altieri and Nicholls, 2007).

Veres et al. (2013) in a literature review found that, in most cases, there is an effect on pest control according to the field composition; especially those with a high proportion of semi-natural areas.

It is proposed that the integrated pest management includes mechanical, physical and cultural control, host resistance, biological control, autocide control, chemical, biochemical and bio-rational agents, and conventional pesticides. Within the biological control weed management as part of conservation is included (Gurr et al., 2004).

In addition, strategies have been look at to improve the sustainability of the field crops by increasing the population of parasitoids or predators introducing secondary plants that provide specific functions like generators of specific pollen or longer flowering duration, providing better conditions for the natural enemies (Barberi et al., 2010; Gurr et al., 2003).

Now, particularly in citrus, Aubert (1987) and Michaud (2004) mentioned that the predators are a group of natural enemies that contributes to controlling $D$. citri. They stated that the most important species are Syrphids, Coccinellids, Chrysopids, and spiders, from greater to lesser importance, which coincides with the present study. Lomelí et al. (2010), also agrees with the previous authors, mentioning that there are seven Coccinellids species in the state of Veracruz, which have been seen feeding on $D$. citri nymphs.

\section{Total number of weeds per treatment}

As expected, no-weed treatments were statistically lower in a number of plants, showing zero tendencies, compared to weed treatments (Table 4). Weed treatments had a similar behavior during the evaluation period of the experiment, although in the last evaluation date a decrease was presented, because environmental conditions lowered weed growth, while at 
the same time some resulted to be dominant, thus preventing germination and growth of other weeds.

Table 4. Total number of insects per square meter of 'Ortanique' orchard fields, in Tuxpan, Veracruz, Mexico, with weed and no-weed treatments

\begin{tabular}{c|c|c|c}
\hline Treatment & First period & Second period & Third period \\
\hline M+A & $227.56 \mathrm{a}$ & $201.04 \mathrm{a}$ & $198.34^{\mathrm{a}}$ \\
$\mathrm{M}-\mathrm{A}$ & $2.86 \mathrm{c}$ & $1.89 \mathrm{c}$ & $2.31 \mathrm{c}$ \\
$\mathrm{I}+\mathrm{A}$ & $165.41 \mathrm{~b}$ & $143.27 \mathrm{~b}$ & $139.56 \mathrm{~b}$ \\
$\mathrm{I}-\mathrm{A}$ & $4.94 \mathrm{c}$ & $3.82 \mathrm{c}$ & $4.03 \mathrm{c}$ \\
\hline
\end{tabular}

$\mathrm{M}+\mathrm{A}=$ Mesh and weed treatments, $\mathrm{M}-\mathrm{A}=$ Mesh and no-weed treatments, $\mathrm{I}+\mathrm{A}=$ Open field and weed treatments, I-A = Open field and no-weed treatments. Means with the same letter in each column do not differ statistically (Tukey, $\alpha \leq 0.05$ )

In the present experiment, we concluded that with more weeds present the less number of $D$. citri adults and nymphs are found. This is consistent with the study carried out by Ortega et al. (2011) on Diaphorina citri abundance and their association with entomophagous in citrus fields and under different weed management systems, stating that the pest incidence is low when trees are planted in low density and invested with weeds, creating unfavorable conditions for the psyllid.

As was observed during data collection and according to the consulted literature, weeds are an important component for insect habitat; the weed species found during sampling were: Bidens odorata, Vigna unguiculata, Melampodium divaricatum, Momordica charanthia, mimosa, Euphorbia heterophylla, Euphorbia prostrata, Euphorbia brasiliensis, Euphorbia hysopilia and grasses such as Setaria sp, Lepthochloa filiformis among others (Altieri and Whitcomb, 1979).

The most prevalent species was Bidens odorata, belonging to the composite family. This could influence large numbers of predators and other insects, as mentioned by Ortega et al. (2011) in studying D. citri abundance associated with entomophagy in citrus fields with different weed management systems. The dicotyledonous families with the highest number of species were Asteraceae and Euphorbiaceae. Altieri and Whitcomb (1979) also mention that certain weeds (Apiaceae, Fabaceae, and Asteraceae) plays an important ecological role as they host and maintain a set of beneficial arthropods that helps to eliminate pest populations.

In order for the mentioned species to present themselves certain conditions are required favoring insect populations. In this respect, Altieri and Whitcomb (1979) found that in the presence of weeds there is an increase of phytophagous population that are associated with them, thereby increasing their predator's populations and parasitoids. They also maintain plant diversity in and out of cultivated fields by improving the availability of alternative food, breeding sites and shelter for important beneficial organisms. Blanco and Leyva (2007) mentioned that beneficial insects are more likely to find alternative prey, covering, breeding sites and refuges.

\section{Gas exchange in 'Ortanique' leaves in Tuxpan, Veracruz}

No significant statistical differences were found (Table 5) in comparing photosynthesis, stomatal conductance, and photosynthetically active radiation between weed and no-weed 
treatments. This concludes that the weeds do not significantly affect photosynthesis, conductance or photosynthetically active radiation in 'Ortanique' mandarins.

Table 5. Gas exchange in 'Ortanique' leaves in the presence of weed and no-weed treatments, in Tuxpan, Veracruz, Mexico

\begin{tabular}{c|c|c|c|c|c}
\hline Treatment & $\mathbf{n}$ & $\mathbf{A}$ & & $\mathbf{g s}_{\mathrm{s}}$ & PAR \\
\hline Weed & 18 & $9.9 \mathrm{a}$ & & $272.6 \mathrm{a}$ & $642 \mathrm{a}$ \\
No-weed & 18 & $10.7 \mathrm{a}$ & & $196.4 \mathrm{a}$ & $542 \mathrm{a}$ \\
\hline
\end{tabular}

Net photosynthesis rate $\left(\mathrm{A}, \mathrm{mol} \mathrm{m} \mathrm{m}^{-2} \mathrm{~s}^{-1}\right)$, stomatal conductance $\left(\mathrm{g}_{\mathrm{s}}, \mathrm{mmol} \mathrm{m}^{-2} \mathrm{~s}^{-1}\right)$ and photosynthetically active radiation (PAR, mmol m $\mathrm{m}^{-2}$ ). Means with the same letter in each column differ statistically, Tukey $(\alpha \leq 0.05)$

In contrast, the presence of the mesh reduced the radiation by $56 \%$, resulting in a $29 \%$ decrease in photosynthesis. Leaf temperature was reduced by $1{ }^{\circ} \mathrm{C}$. (Table 6 )

Table 6. Gaseous exchange in 'Ortanique' leaves growing with and without the mesh structure, in Tuxpan, Veracruz, Mexico

\begin{tabular}{c|c|c|c|c|c|c}
\hline Treatment & $\mathbf{n}$ & $\mathbf{A}$ & Th & $\mathbf{g s}_{\mathrm{s}}$ & PAR & Ta \\
\hline Without mesh & 18 & $12.0 \mathrm{a}$ & $25.3 \mathrm{a}$ & $275.3 \mathrm{a}$ & $824 \mathrm{a}$ & $25.1 \mathrm{a}$ \\
With mesh & 18 & $8.6 \mathrm{~b}$ & $24.3 \mathrm{~b}$ & $193.7 \mathrm{~b}$ & $359.3 \mathrm{~b}$ & $24.4 \mathrm{~b}$ \\
\hline
\end{tabular}

Net photosynthesis rate $\left(\mathrm{A}, \mathrm{mol} \mathrm{m} \mathrm{m}^{-2}\right)$, leaf temperature $\left(\mathrm{Th},{ }^{\circ} \mathrm{C}\right)$, stomatal conductance $\left(\mathrm{g}_{\mathrm{s}}, \mathrm{mmol} \mathrm{m}^{-2}\right.$ $\mathrm{s}^{-1}$ ) and photosynthetically active radiation (PAR, mmol $\left.\mathrm{m}^{-2} \mathrm{~s}^{-1}\right)$, and air temperature $\left(\mathrm{Ta} ;{ }^{\circ} \mathrm{C}\right)$. Means with the same letter in each column differ statistically, Tukey $(\alpha \leq 0.05)$

\section{Nutrient analysis of 'Ortanique' mandarins and weeds, in Tuxpan, Veracruz, Mexico}

Table 7 presents the nutritional diagnosis of mandarins leaves under different weed and mesh treatments. In this table we can observe that there are statistical differences in the nutritional content of $\mathrm{N}, \mathrm{P}, \mathrm{Ca}, \mathrm{Fe}$ and $\mathrm{Zn}$, of mandarin leaves, under the different treatments. The 'Ortanique' trees grown with mesh and weed treatment had the highest $\mathrm{N}$ and $\mathrm{Fe}$ concentration in leaves, in relation to other treatments. On the other hand, the no-weed and mesh treatment showed higher $\mathrm{P}$ and $\mathrm{Zn}$ concentration.

There is no clear tendency of the influence of weeds on the different nutrient concentrations in 'Ortaniques' subjected to the weed treatments and with/without mesh, in Tuxpan, Veracruz, Mexico.

When foliar nutritional diagnosis was carried out on the weeds, it was noted that a high amount of nutrients was extracted, as observed in Table 8.

Table 7. Nutritional diagnosis of 'Ortanique' mandarin leaves, with different mesh and weed treatments, in Tuxpan, Veracruz, Mexico

\begin{tabular}{c|c|c|c|c|c|c|c}
\hline Treatment & $\mathbf{N}(\%)$ & $\mathbf{P}(\%)$ & $\mathbf{K}(\%)$ & $\mathbf{C a}(\%)$ & $\mathbf{M g}(\boldsymbol{\%})$ & $\mathbf{F e}\left(\mathbf{m g ~ k g}^{-1}\right)$ & $\mathbf{Z n}\left(\mathbf{m g ~ k g}^{-1}\right)$ \\
\hline No mesh and no weeds & $1.04 \mathrm{~b}$ & $0.11 \mathrm{a}$ & $1.6 \mathrm{a}$ & $2.84 \mathrm{ab}$ & $0.07 \mathrm{a}$ & $124 \mathrm{bc}$ & $198 \mathrm{a}$ \\
No mesh and weeds & $1.14 \mathrm{~b}$ & $0.06 \mathrm{~b}$ & $1.56 \mathrm{a}$ & $3.04 \mathrm{a}$ & $0.05 \mathrm{a}$ & $148 \mathrm{~b}$ & $147 \mathrm{~b}$ \\
Mesh and no weeds & $1.15 \mathrm{~b}$ & $0.07 \mathrm{ab}$ & $1.6 \mathrm{a}$ & $2.71 \mathrm{~b}$ & $0.06 \mathrm{a}$ & $99 \mathrm{c}$ & $111 \mathrm{c}$ \\
Mesh and weeds & $1.4 \mathrm{a}$ & $0.04 \mathrm{~b}$ & $1.56 \mathrm{a}$ & $2.56 \mathrm{~b}$ & $0.06 \mathrm{a}$ & $188 \mathrm{a}$ & $95 \mathrm{~d}$ \\
\hline
\end{tabular}

Means with different letter in columns differ significantly, Tukey $(\alpha \leq 0.05)$ 
Table 8. Plant tissue analysis of weeds, in Tuxpan, Veracruz, Mexico

\begin{tabular}{|c|c|c|c|c|c|c|c|}
\hline Weed type & $\mathbf{N}(\%)$ & $\mathbf{P}(\%)$ & $\mathrm{K}(\%)$ & $\mathrm{Ca}(\%)$ & $\mathrm{Mg}\left(\mathrm{mg} \mathrm{kg}^{-1}\right)$ & $\mathrm{Fe}\left(\mathrm{mg} \mathrm{kg}^{-1}\right)$ & $\mathrm{Zn}\left(\mathrm{mg} \mathrm{kg}^{-1}\right)$ \\
\hline Broad leaves & 3.29 & 0.12 & 0.87 & 0.28 & 256 & 158 & 233 \\
\hline Grasses & 3.47 & 0.02 & 1.39 & 0.23 & 234 & 360 & 514 \\
\hline Average & 3.38 & 0.07 & 1.13 & 0.25 & 245 & 259 & 373 \\
\hline
\end{tabular}

On average, $3.38 \%$ of nitrogen was extracted. This means that for every $100 \mathrm{~kg}$ of weed dry matter produced, $3 \mathrm{~kg}$ of nitrogen were absorbed from the soil. This is of great disadvantage to common weeds that consume high amounts of nutrients, hence the importance of establishing legumes as live mulch that would fix atmospheric nitrogen although the extraction of other nutrients must be considered.

It has been frequently mentioned that weeds compete for nutrients and water with the interest crop considerably affecting their development. Under this experimental condition, 'Ortanique' mandarins grown with or without meshes and with or without weeds showed statistically different foliar nutritional contents. Nitrogen, an important element for the development of citrus fruits, had a higher concentration in the mesh and weed treatment.

\section{Conclusions}

The number of $D$. citri adults and nymphs was significantly reduced in 'Ortanique' mandarins, located at Tuxpan, Veracruz, Mexico, by the presence of weeds and mesh treatments. The number of insects in mandarins cultivar 'Ortanique', were greater when weeds were present. Higher nitrogen concentration was obtained in mandarins trees growing together in weed treatments with or without mesh. Photosynthesis, stomatal conductance, and photosynthetically active radiation in 'Ortanique' trees were not affected by the presence of weeds in Tuxpan, Veracruz, Mexico.

\section{REFERENCES}

[1] Ali, J. G., Agrawal, A. A. (2014): Asymmetry of plant-mediated interactions between specialist aphids and caterpillars on two milkweeds. - Funcional Ecolgy 28: 1404-1412.

[2] Altieri, M. A., Nicholls, C. I. (2007): Conversion agroecologica de sistemas convencionales de produccion: teoria, estrategias y evaluacion. - Ecosistemas 16(1): 312.

[3] Altieri, M. A., Whitcomb, W. H. (1979): The potential use of weeds in the manipulation of beneficial insects. - HortScience 14(1): 12-18.

[4] Álvarez, S., Rohrig, E., Solís, D., Thomas, M. H. (2016): Citrus greening disease (Hoanglongbing) in Florida: Economic impact, management and the potential for biological control. - Agric. Res. 5(2): 109-118.

[5] Andorno, A. V., Lopez, S. N. (2014): Biological control of Myzus persicae (Hemiptera: Aphididae) through banker system in protected crops. - Biological Control 78: 9-14.

[6] Atakan, E. (2010): Influence of weedy field margins on abundance patterns of the predatory bugs Orius spp. and their prey, the western flower thrips (Frankliniella occidentalis), on faba bean. - Phytoparastica 38: 313-325. 
[7] Aubert, B. (1987): Trioza erytreae del Guercio and Diaphorina citri (Homoptera: Psylloidea), the two vectors of the citrus greening disease: Biological aspects and possible control strategies. - Fruits 42: 149-162.

[8] Banks, J. E., Gagic, V. (2016): Aphid parasitoids respond to vegetation heterogeneity but not to fragmentation scale: An experimental field study. - Basic and Applied Ecology 17: 438-446.

[9] Barberi, P., Burgio, G., Dinelli, G., Moonen, A. C., Otto, S., Vazzana, C., Zanin, G. (2010): Functional biodiversity in the agricultural landscape: relationships between weeds and arthropod fauna. - Weed Research 50: 388-441.

[10] Belasque, J., Bassanezi, R. B., Yamamoto, P. T., Ayres, A. J., Tachibana, A., Violante, A. R., Tank, A., Di Giorgi, F., Tersi, F. E. A., Menezes, G. M., Dragone, J., Jank, R. H., Bove, J. M. (2010): Lessons from hunglongbing management in Sao Paulo State, Brazil. - Journal of Plant Pathology 92: 285-302.

[11] Blanco, Y. Y, Leyva, A. (2007): Las arvenses en el ecosistema y sus beneficios agroecológicos como hospederas de enemigos naturales. - Cultivos Tropicales 28(2): 2128.

[12] Boivin, G., Hance, T., Brouder, J. (2012): Aphid parasitoids in biological control. Canadian Journal of Plant Science 92: 1-12.

[13] Bové, J. M. (2006): Huanglongbing: a destructive, newly-emerging, century old disease of citrus. - J. Plant Pathol. 88: 7-37.

[14] Chen, J., Pu, X., Deng, X., Liu, S., Li, H., Civerolo, E. (2009): A phytoplasma related to "Candidatus phyto-plasma asteri" detected in citrus showing Huanglong-bing (yellow shoot disease) symptoms in Guangdong, P. R. China. - Phytopatology 99: 236-242.

[15] Chiou-Nan, C. (1998): Ecology of the Insect Vectors of Citrus Systemic Diseases and Their Control in Taiwan. - FFTC Publication Database, Taiwan.

[16] Colloff, M. J., Lindsay, E. A., Cook, D. C. (2013): Natural pest control in citrus as an ecosystem service: integrating ecology, economics and management at the farm scale. Biological Control 67: 170-177.

[17] Comisión Nacional del Agua (2014): Base de datos climáticos de Tuxpan, Veracruz, México. - Secretaría del Medio Ambiente y Ecología, México.

[18] Dahlin, I., Ninkovic, V. (2013): Aphid performance and population development on their host plants is affected by weed-crop interactions. - Journal of Applied Ecology 50(5): 1281-1288.

[19] De la Cruz, E. (2014): Cinética poblacional y distribución espacial de Diaphorina citri Kuwayama sobre naranja valencia en el Norte de Veracruz. - Tesis de Doctorado, Universidad Autónoma Chapingo.

[20] Etchevers, B. (2001): Manual de procedimientos análiticos para análisis de suelo y planta en el Laboratorio de Fertilidad de suelos. - IRENAT. Ed. Colegio de Posgraduados. Sociedad Mexicana de la Ciencia del Suelo. Montecillo, Estado de México.

[21] Grafton-Cardwell, E. E., Stelinski, L. L., Stansly, P. A. (2013): Biology and management of Asian Citrus Psyllid, vectot of the Huanglongbing pathogens. - Annu. Rev. Entomol. 58: 413-432.

[22] Gurr, G. M., Wratten, S. D., Luna, J. M. (2003): Multi-function agricultural biodiversity: pest management and other benefits. - Basic and Applied Ecology 4: 107-116.

[23] Gurr, G. M., Wratten, S. D., Altieri, M. A. (eds.) (2004): Ecological Engineering for Pest Management-Advances in Habitat Manipulation for Arthropods. - CSIRO Publishing, Melbourne, Australia.

[24] Halbert, S. E., Manjunath, K. L. (2004): Asian citrus psyllids (Sternorrhyncha: Psyllidae) and greening disease in citrus: a literature review and assessment of risk in florida. Florida Entomologist 87: 330-353.

[25] Hall, D. G.; Hentz, M. G., Adair, R. C. Jr. (2008): Population ecology and phenology of Diaphorina citri (Hemiptera: Psyllidae) in two Florida citrus groves. - Environmental Entomology 37(4): 914-924. 
[26] Kumar, S. (2017): Potential of Ethiopian mustard, Brassica Carinata as a trap crop for large white butterfly, pieris brassicae infesting indian mustard, brassica juncea. - Pest Sci. 90: 129-137.

[27] Liu, Y. H., Tsai, J. H. (2000): Effects of temperature on biology and life table parameters of the Asian citrus psyllid, Diaphorina citri Kuwayama (Homoptera: Psyllidae). - Ann. Applied Biol.137: 201-216.

[28] Lomelí, F. J. R., Rodríguez, L. E., Valdez, J. M., Ortega, A. L. D. (2010): Géneros de Coccinellidae asociados a Diaphorina citri (Hemiptera: Psyllidae) en México. - 1er Simposio Nacional sobre Investigación para el Manejo del Psílido Asiático de los Críticos y el Huanglongbing en México. Monterrey, N. L., Méx., pp. 64-77.

[29] Macfadyen, S., Hopkinson, J., Parry, H., Neave, M. J., Bianchi, F. J. J. A., Zalucki, M. P., Schellhorn, N. A. (2015): Early-season movement dynamics of phytophagous pest and natural enemies across a native vegetation -crop ecotone. - Agriculture, Ecosystems and Environment 200: 110-118.

[30] Martínez, C. J. L. (2011): Diaphorina citri Kuwayana Psílido de los cítricos. SAGARPA- SENASICA-SINAVEF. Ficha técnica. México. pp. 18.

[31] May-Tzun, R. C., Almaguer Vargas, G., Munguía-Rosales, R., Sánchez Borja, M. (2015): Identificación de factores que permiten la convivencia de Diaphorina citri con cítricos en Yucatán. 363-379. - Desarrollo y tecnología. Aportaciones a los problemas de la sociedad. Eds. César Santiago Tepantlán, Alma Velia Ayala Garay Gustavo Almaguer Vargas. Plaza y Valdez. México.

[32] Michaud, J. P. (2004): Natural mortality of asian citrus psyllid (Homoptera): psillidae in central Florida. - Biological Control 29: 260-269.

[33] Monzo, C., Qureshi, J. A., Stansly, P. A. (2014): Insecticide sprays, natural enemy assemblage and predation on Asian citrus psyllid, Diaphorina citri (Hemiptera: Psyllidae). - Bulleting of Entomological Research 104: 576-585.

[34] Nave A, Goncalves, F., Crespi, A. L., Campos, M., Torres, L. (2016): Evaluation of native plant flower characteristics for conservation biological control of Prays oleae. Bulletin of Entomological Research 106: 249-257.

[35] Ortega, A. J. R., López, L. L., Lomelí, F., Cedillo, E. P. L., Gómez, T., Salazar, C. (2011): Abundancia de Diaphorina citri y entomófagos asociados en huertos citrícolas con diferentes sistemas de manejo de arvenses. - 2. Simposio Nacional sobre investigación para el manejo del Psilido Asiático de los Cítricos y el Huanglongbing en México.

[36] Ortega, A. L. D., Villegas, A. M., Ramírez, A. J. R., Mendoza, E. E. G. (2013): Abundancia estacional de Diaphrina citri (Hemiptera: Liviidae) en plantaciones de cítricos en Cazones, Veracruz, México. - Acta de Zoología México 29(2): 317-333.

[37] Parolin, P., Bresch, C., Desneux, N., Brun, R., Bout, A., Boll, R., Poncet, C. (2012): Secondary plants used in biological control: a review. - International Journal of Pest Management 58: 91-100.

[38] Qureshi, J., Rogers, M., Hall, D., Stansly, P. (2009): Incidence of invasive Diaphorina citri (Hemiptera:Psyllidae) and its introduced parasitoid Tamarixia radiata (Hymenoptera: Eulophidae) in Florida citrus. - J. Econ Entomol. 102: 247-256.

[39] Robles-González, M. M., Velázquez-Monreal, J. J., Manzanilla-Ramírez, M. Á., OrozcoSantos, M., Medina-Urrutia, V. M., López-Arrollo, J. I., Flores-Virgen, R. (2013): Síntomas del Huanglongbing (HLB) en arboles de limón mexicano [Citrus aurantifolia (Christm) Swingle] y su dispersion en el estado de Colima, Mexico. - Revista Chapingo Serie Horticultura. 19(1): 15-31.

[40] Salcedo, B. D., Hinojosa, R., Mora, G., Covarrubias, I., DePaolis, F., Cintora, C., Mora, S. (2010): Evaluación del Impacto Económico de Huanglonbing (HLB) en la Cadena Citrícola Mexicana. - IICA, México.

[41] SAS (2014): The SAS® System for Window ${ }^{\circledR}$. - SAS Institute Inc., Cary, NC. 
[42] SAGARPA-SIAP. Secretaria de agricultura, ganadería, pesca y alimentación (SAGARPA). (2016): Base de datos del Servicio de Información Agrolimentaria y Pesquera. - SIAP, México.

[43] Thomson, L. J., Hoffmann, A. A. (2009): Vegetation increases the abundance of natural enemies in vineyards. - Biological Control 49: 259-269.

[44] Thomson, L. J., Hoffmann, A. A. (2010): Natural enemy responses and pest control: importance of local vegetation. - Biological Control 52: 160-166.

[45] Tiwari, S., Mann, R., Rogers, M., Stelinski, L. (2011): Insecticide resistance in field populations of Asian citrus psyllid in Florida. - Pest Manag Sci. 67: 1258-1268.

[46] Tomaseto, A. F, Krugner, R., Lopes, J. R. S. (2016): Effect of plant barriers and citrus leaf age on dispersal of Diaphorina citri (Hemiptera: Liviidae). - J. Appl. Entomol. 140: 91-102.

[47] Veres, A., Petit, S., Conord, C., Lavigne, C. (2013): Does landscape composition affect pest abundance and their control by natural enemies? A review. - Agriculture, Ecosystems and Environment 166: 110-117.

[48] Vialatte, A., Tsafack, N., Al Hassan, D., Duflot, R., Plantegenest, M. Ouin, A., VillenaveChasset, J., Ernoult, A. (2017): Landscape potential for pollen provisioning for beneficial insects favours biological control in crop fields. - Landscape Ecol. 32: 465-480. 